\title{
Analysis of the Impact of Land Use and Occupation on the Biophysical Variables of the Cerrado Biome in Southwest Goiano, Brazil
}

\author{
Victor H. Moraes ${ }^{1}$, Pedro R. Giongo ${ }^{2}$, Marcio Mesquita ${ }^{3}$, Thomas J. Cavalcante ${ }^{1}$, Matheus V. A. Ventura ${ }^{1}$, \\ Estevam M. Costa $^{1} \&$ Bruno H. T. Arantes ${ }^{1}$ \\ ${ }^{1}$ Goiano Federal Institute, Rio Verde, Brazil \\ ${ }^{2}$ School of Agricultural Engineering, State University of Goiás, Santa Helena de Goiás, Brazil \\ ${ }^{3}$ School of Agronomy, Federal University of Goiás, Goiania, Brazil \\ Correspondence: Victor H. Moraes, Goiano Federal Institute, Rio Verde, Brazil. Tel: 55-64-99951-0678. E-mail: \\ victor.cm1@hotmail.com
}

Received: October 2, 2018

Accepted: November 1, 2018 Online Published: December 15, 2018

doi:10.5539/jas.v11n1p399

URL: https://doi.org/10.5539/jas.v11n1p399

\begin{abstract}
The change in the use of natural vegetation by annual or perennial crops, sugarcane and fast-growing forests causes changes in the biophysical variables, and these changes can be monitored by remote sensing. The objective of this work was to evaluate, on a temporal scale, the impacts of land use changes on biophysical variables in the county of Santa Helena de Goias-Goias/Brazil. Between the years of 2000 to 2015 areas were identified for agricultural crops 1 (annual crops), water, agricultural crops 2 (sugarcane), natural vegetation, pasture and urban areas. The MODIS (Moderate Resolution Spectroradiometer) sensor products were selected for study: MOD11A2-Surface temperature; MOD16A2-Real evapotranspiration, MOD13Q1-Enhanced Vegetation Index and rainfall data from TRMM (Tropical Rainfall Measuring Mission). The geographic coordinates referring to the land uses were inserted in the LAPIG platform, searching the information of the biophysical variables referring to the selected pixel. The impact of land use change was evaluated by calculating the weighted average through the quantitative classification of the areas. It is concluded for the period of study that the index of average vegetation of the county had increase. There was an increase in the evapotranspiration volume of the county from $28 \%$ from 2000 to 2013 and the average surface temperature of the county showed a reduction of $2{ }^{\circ} \mathrm{C}$ in the period from 2000 to 2015 .
\end{abstract}

Keywords: index of vegetation, geotechnologies, TRMM, MODIS, surface temperature, evapotranspiration

\section{Introduction}

The Brazilian territory consists of approximately $22 \%$ of the Cerrado Biome. Currently agricultural expansion has increased disorderly occupation of this biome, and consequently, mitigating native flora and limiting natural resources and biodiversity (Caldas et al., 2009). The Southwest Goiano is a region inserted at Brazilian Savanna (Cerrado) which is characterized by having good soil to agriculture and livestock (fertility, depth and flat relief) (Franco, 2014; Ferreira, 2009). Rodrigues et al. (2009), and Paranhos-Filho et al. (2014) point out that biomes, when they are decharacterised by anthropic actions, either by suppressing native vegetation or due to incorrect management, suffer impacts on the sustainability of the ecosystem, which may lead to changes in the microclimate of the region.

Changes in soil use by agroecosystems, such as; annual or perennial crops, pastures, and fast-growing forests, cause changes in the physical properties of the soil surface and in the regional biophysical constitution, such as; in evapotranspiration, surface albedo, vegetation indices, surface temperature, radiation balance, soil and latent heat fluxes, among others, which serve as indicators of changes in the climate patterns of a region (Cunha et al., 2012; Loarie et al., 2011). Risso et al. (2012) suggests vegetation index as a variable that allows understanding the change of land use and occupation, as it varies according to the spectral response of the surface, being sensitive to the alteration of the soil use.

Studies on the use of areas of natural vegetation by sugarcane showed that this action promotes reduction in the balance of radiation, in the annual average evapotranspiration and in the increase of the surface temperature. 
(Gomes, 2009). Negrón-Juarez (2004) identified changes in the pattern of spatial distribution of precipitation and temperature when natural vegetation was replaced by sugarcane, annual crops and pasture.

Biophysical variables can be monitored in the field or remotely. While the monitoring of large-scale biophysical variables is not feasible with the use of in situ instruments, sensors embedded in satellites allow studies of high spatial and temporal reliability in the periodic coverage of large areas (Souza et al., 2016). If there is a change in the use of the soil, there will be a change in the amount of energy that is absorbed, transmitted and reflected by the surface (Feitosa et al., 2011).

Remote Sensing has assumed great importance in monitoring changes in land use in relatively large areas and difficult access regions, generating information necessary for the management of soil and natural resources (Shi \& Song, 2015). It is also able to obtain information on biophysical variables such as: surface temperature, precipitation, evapotranspiration, albedo, latent heat, among others, through orbital sensors. It has a low cost of data acquisition and still has a strong relationship with data measured in the field (Bezerra et al., 2014; Gallo \& Xian, 2014; Lopes et al., 2010; Oliveira et al., 2012).

Some of the several products that have been performing great results in the monitoring of biophysical variables are the Tropical Rainfall Measuring Mission (TRMM) and the Moderate Resolution Imaging Spectroradiometer (MODIS). The TRMM ships several sensors, such as precipitation radar (PR), microwave imager (TMI) and visible infrared radiometer (VIRS), forming by-product 3B43 that provides precipitation data in $\mathrm{mm} \cdot \mathrm{h}^{-1}$ (Almazroui, 2011). The TRMM has a significant correlation when compared to the aferic precipitation data in meteorological stations (Alves et al., 2017).

MODIS is on board the Terra and Aqua platforms (Cuba et al., 2018). It consists of an optical scanning transverse scanner and a set of detector elements where its purpose is to monitor changes in soil cover, conditions and productivity (Tangdamrongsub et al., 2016). Formed by six byproducts, the MODIS sensor records the following images: land surface reflectance, land surface temperature $\left({ }^{\circ} \mathrm{C}\right)$, vegetation index, leaf area index, evapotranspiration $(\mathrm{mm})$ and net primary productivity.

In this context, the objective of this work was to evaluate, on a temporal scale, the impacts of land use changes on the biophysical variables for the county of Santa Helena de Goias-Goias/Brazil. However, information is expected to assist managers in planning and making decisions about the impacts and consequences of such changes.

\section{Method}

The study was carried out in Santa Helena de Goias-Goias/Brazil, located between latitudes: $18^{\circ} 04^{\prime} 48^{\prime \prime} \mathrm{S}$ and $17^{\circ} 33^{\prime} 14^{\prime \prime} \mathrm{S}$ and longitudes: 50 $49^{\prime} 12^{\prime \prime} \mathrm{W}$ and $50^{\circ} 20^{\prime} 02^{\prime \prime} \mathrm{W}$ (Figure 1). The climate of the region is classified according to Koppen-Geiger type Aw (tropical), with rainy season in summer and dry season in winter, with average annual rainfall of $1539 \mathrm{~mm}$, average air temperature of $24.3^{\circ} \mathrm{C}$ (Alvares et al., 2013).
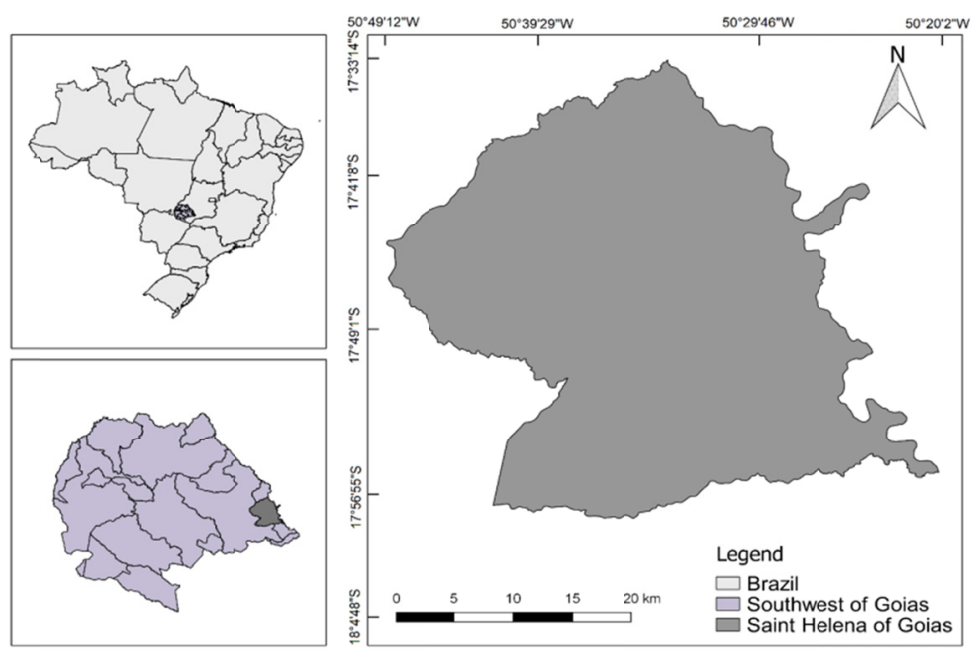

Figure 1. Geographic location of the country of Santa Helena de Goias-Goias

Source: Archives of the boundaries of the counties of the state of Goias (SIEG, 2016) prepared by the first author. 
In the period from 2000 to 2015 were identified areas occupied by agricultural cultivation 1 (annual crops), water, agricultural cultivation 2 (sugarcane), natural vegetation, pasture and urban from the database of the Laboratory of Image Processing and Geoprocessing (LAPIG, 2016), from the DGI-INPE database (INPE, 2016), and the United States Geological Survey (USGS), (USGS, 2016). The geographic coordinates referring to the land uses in the LAPIG platform were inserted, where the filtering takes place of the images referring to the past of the satellite, providing the information of the biophysical variables referring to the selected pixel. The geographical coordinates correspond to the pixels selected in the interactive LAPIG map found in Table 1. Five pixels were selected for each soil use and the mean of these pixels was calculated.

Table 1. Central geographic coordinates of the areas sampled with land use and occupation in the county of Santa Helena de Goias from 2000 to 2015

\begin{tabular}{llc}
\hline \multirow{2}{*}{ Uses of soil } & \multicolumn{2}{c}{ Geographic Coordinates } \\
\cline { 2 - 3 } & Longitude & Latitude \\
\hline Areas of agricultural crops 1 (AAC1) & -50.6869 & -17.7022 \\
Water & -50.3955 & -18.8148 \\
Areas of agricultural crops 2 (AAC2) & -50.5044 & -17.8460 \\
Natural vegetation & -50.5488 & -17.7872 \\
Pasture & -50.4929 & -17.9014 \\
Urban & -50.6011 & -17.8133 \\
\hline
\end{tabular}

The MODIS (Moderate Resolution Imaging Spectroradiometer) sensor products were selected for this study: MOD11A2-Surface Temperature (ST); MOD16A2-Real Evapotranspiration (ETR), MOD13Q1-Enhanced Vegetation Index 2 (EVI2) and TRMM (Tropical Rainfall Measuring Mission) radar data. The specifications of the sensors to obtain the biophysical variables are found in Table 2. The evapotranspiration data were not obtained until the year 2015 due to its unavailability on the USGS platform with the availability until the year 2013. The EVI2 is determined by the following equation (Equation 1) (Jensen, 2009):

$$
E V 12=2.5 \times \frac{N I R-R e d}{N I R+R e d}
$$

Where, NIR refers to the infrared band and Red to the red band, both of the MODIS sensor.

Table 2. Specification of the sensors to obtain biophysical variables data

\begin{tabular}{|c|c|c|c|}
\hline \multirow{2}{*}{ Products } & \multicolumn{2}{|c|}{ Resolution } & \multirow{2}{*}{ Data period } \\
\hline & Space & Temporal & \\
\hline MOD13Q1 & $0.25 \mathrm{~km}$ & 16 days & $2000-2015$ \\
\hline MOD16A2 & $1.00 \mathrm{~km}$ & 16 days & $2000-2013$ \\
\hline MOD11A2 & $1.00 \mathrm{~km}$ & 8 days & $2000-2015$ \\
\hline TRMM 3B43 & $30.0 \mathrm{~km}$ & Daily & $2000-2015$ \\
\hline
\end{tabular}

The algorithm responsible for the generation of the product MOD16A2 is based on the Penman-Monteith equation (Monteith, 1965), which considers data concerning the evaporation of the earth's surface and the transpiration of the plant canopy. As the surface occupied by water does not have transpiration, the evapotranspiration recorded by MOD16A2 assumes values equal to zero.

Because the spatial resolution of the TRMM radar is $30 \mathrm{~km}$, where a pixel covers several uses of the soil (heterogeneous pixels), the precipitation index that represents the entire county was determined. Five pixels were collected, where they covered the entire county of Santa Helena de Goias. Then the calculation of the average of the values corresponding to the five pixels was carried out, determining the monthly average and the annual accumulation of rainfall. For ST, EVI2 and ETR, the data were extracted from the pixels for each type of soil use, obtaining the monthly and annual average for each of them. All the data were tabulated for the elaboration of the annual and monthly averages of the biophysical variables, being able to evaluate the patterns of each one in temporal scale for each use and occupation of the soil. 
The classification of land use and occupation was carried out following the classification suggested by Gomes et al. (2016). The authors used images from LANDSAT 5 (Land Remote Sensing Satellite) to cover all the territory of Santa Helena de Goias belonging to the year 2000, 2005 and 2010 and image of LANDSAT 8 for the year 2015 considering always the orbit/point: 222/72. The images were processed by the software SPRING v. 5.3.0. For the classification used the supervised method, to separate the homogeneous areas. The images were classified into six thematic classes: AAC1 (areas occupied by annual crops), water, AAC2 (areas occupied by sugarcane), natural vegetation, pasture and urban area. Figure 2 presents the quantitative total area for each class of land use.

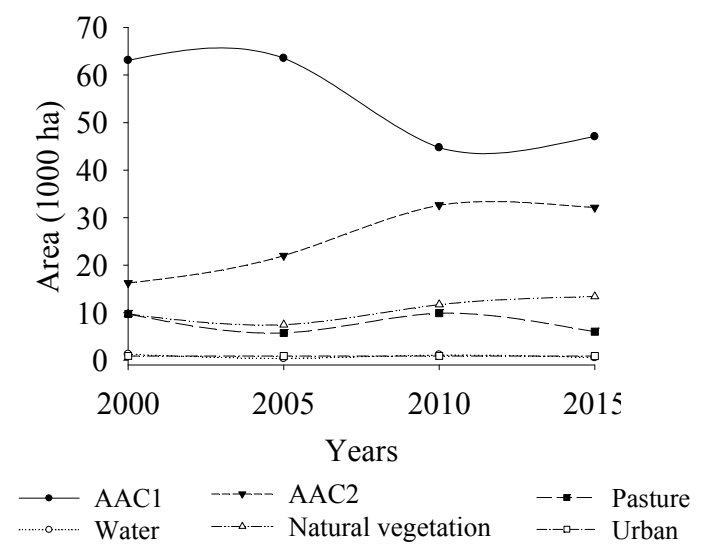

Figure 2. Quantification of land use and occupation from 2000 to 2015, in the county of Santa Helena de Goias, GO

The impact of land use change was evaluated by calculating the weighted average through the quantitative classification of the areas. The following parameters were determined: EVI2 vegetation index (equation 2), surface temperature (equation 3) and real evapotranspiration (equation 4) for the years 2000, 2005, 2010 and 2015. For the calculation of the weighted average, the annual averages of these biophysical variables were used.

$$
\begin{aligned}
& \text { Average EVI2 =EVI2 annual average } \times \% \text { area } \\
& \text { Average } S T=S T \text { annual average }\left({ }^{\circ} \mathrm{C}\right) \times \% \text { area } \\
& \text { Average ETR }=\text { ETR annual average }(\mathrm{mm}) \times \% \text { area }
\end{aligned}
$$

\section{Results and Discussion}

\subsection{Index Vegetation (EVI2)}

Figures 3A and 3B present the EVI2 graphs for the annual and monthly mean between 2000 and 2015 and Figure 3C shows the behavior of the EVI2 of the county between 2000 and 2015.

By analyzing the graphs for the study period, it is observed that the area occupied by water assumed the lowest values of EVI2 due to high energy absorption and low reflectance at almost all the wavelengths of the electromagnetic spectrum (Figure 3A). However, the area occupied by natural vegetation was the one with the highest EVI2, due to the high vegetative vigor of the plants. This causes low reflectance of energy to occur in the visible range and higher in the infrared range, due to the high absorption of energy in the visible range for the realization of the photosynthetic processes. Corroborating with Santos and Siqueira (2010) the maximum values of EVI2 for natural vegetation were below 0.5 . The authors justify these results because of the low phenological variation of this vegetation. The areas occupied by pasture presented a spectral behavior similar to the areas occupied by natural vegetation. These results were like those obtained by Andrade et al. (2017), where they describe that these uses have high values of well-defined EVI2 dependent on the season.

It was noticed that the AAC1 began to show an increase in the vegetation index from the month of October. As plants develop, there is an increase in EVI2, where in the months of December and January they reach peak vegetation index of 0.67 (Figure 3B). In the month of October in this region the soybean is planted, so the increase in EVI2 is due to the phenological variation of the soybean during its cycle. As of January, there is a decrease in the vegetation index due to the soybean plants entering the senescence period, where the plant will lose the pigments responsible for the absorption of energy in the visible range, causing it to reflect the (visible) 
energy in it and absorb most of the energy in the near infrared band, reducing EVI2. The decrease in EVI2 occurs until the month of March (soil exposed) and again, there is an increase from that month due to the planting of corn crop in most areas in this region.

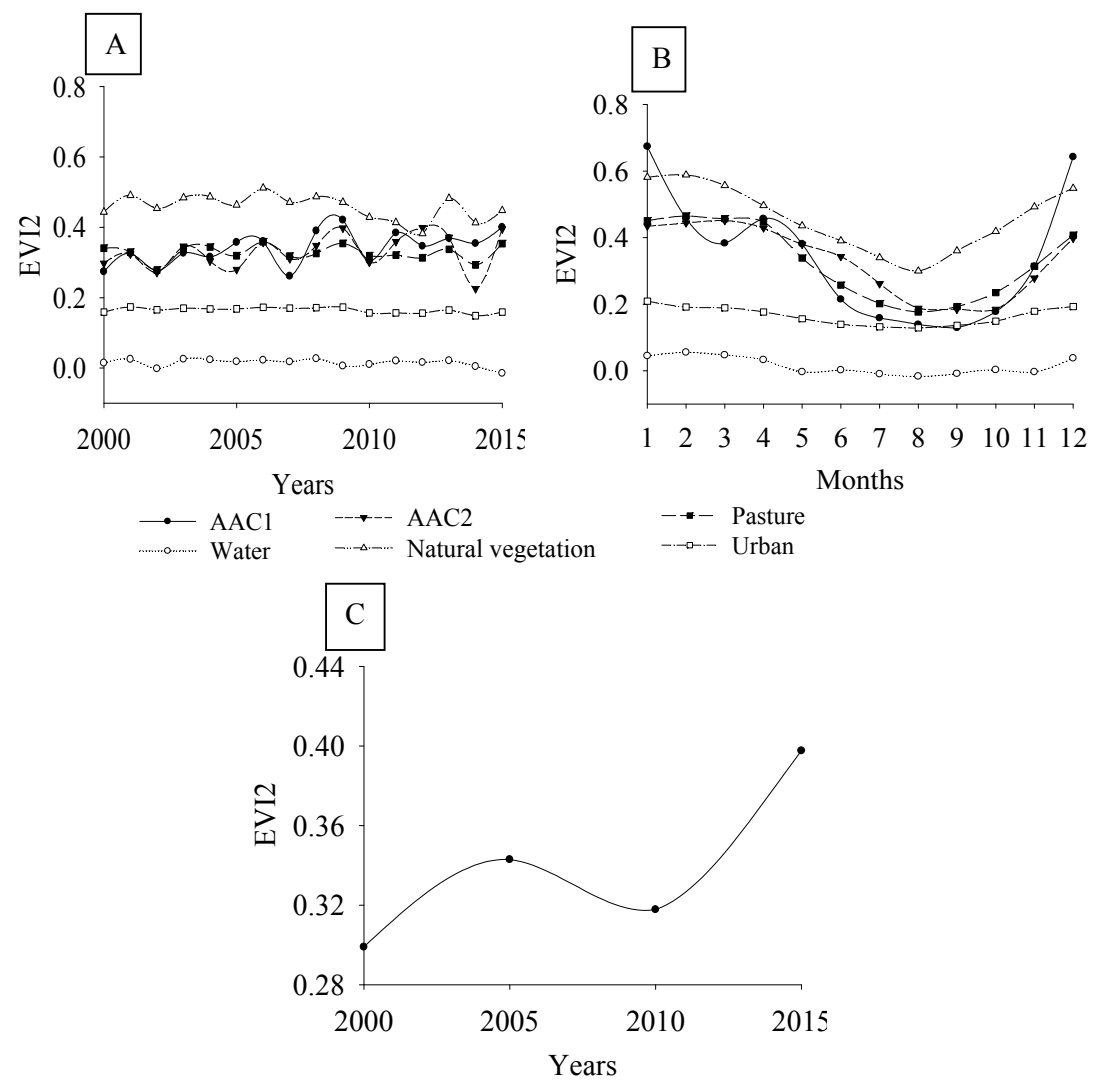

Figure 3. Annual mean (A) and monthly average (B) of EVI2 from 2000 to 2015 for different land uses in the county of Santa Helena de Goias; and EVI2 (C) of the territory of Santa Helena de Goias calculated by the weighted average of all land uses

In the period from June to October, there was a decrease in EVI2 for all soil uses, due to the low volume of precipitation, see Figure 5B, which shows the monthly rainfall distribution. Thus, Leite et al. (2017) points out that vegetation index values are directly related to the water availability of the soil profile, in which in the wet period there were high values. The urban area, presented low EVI2 for most of its surface is occupied by pavements, roofs and little vegetation, differing from AAC1, AAC2 and pasture, subject to surface changes during the periods of the year.

It is verified that with the change in the use and occupation of the soil of natural vegetation for pasture, AAC1, $\mathrm{AAC} 2$, there was a reduction in the vegetation index, where the use of the soil occupied by natural vegetation presented a higher annual average of vegetation index. This change is evident because the areas occupied by natural vegetation are denser, resulting in a greater absorption of energy in the visible range. When the electromagnetic energy in the visible band interacted with the surface occupied by urban area, there was higher energy reflectance in the visible band and lower energy reflectance in the near infrared band, resulting in low EVI2 values. It was evident the use of the soil affects the EVI2, since all the uses of the studied soil, had different spectral behavior (Figures $3 \mathrm{~A}$ and $3 \mathrm{~B}$ ).

Although each soil use had a different spectral behavior, when the behavior of all the land uses together through the weighted mean (EVI2 of the county) was evaluated, there was an increase in EVI2 from the year 2000 to 2015, positively impacting (Figure 3C). This increase in the vegetation index was due to the fact that most of the energy in the surface was absorbed from the vegetation/target, caused by the reduction of degraded pastures and increase of the AAC2 (Figure 2) in the county. The increase in vegetation index favored an increase in evapotranspiration rate (Figure 6C) and reduction in surface temperature (Figure 3C). 


\subsection{Surface Temperature (ST)}

Figures 4A and 4B present the surface temperature graphs for the annual and monthly mean between 2000 and 2015 and Figure 3C shows the behavior of the surface temperature of the county between 2000 and 2015.

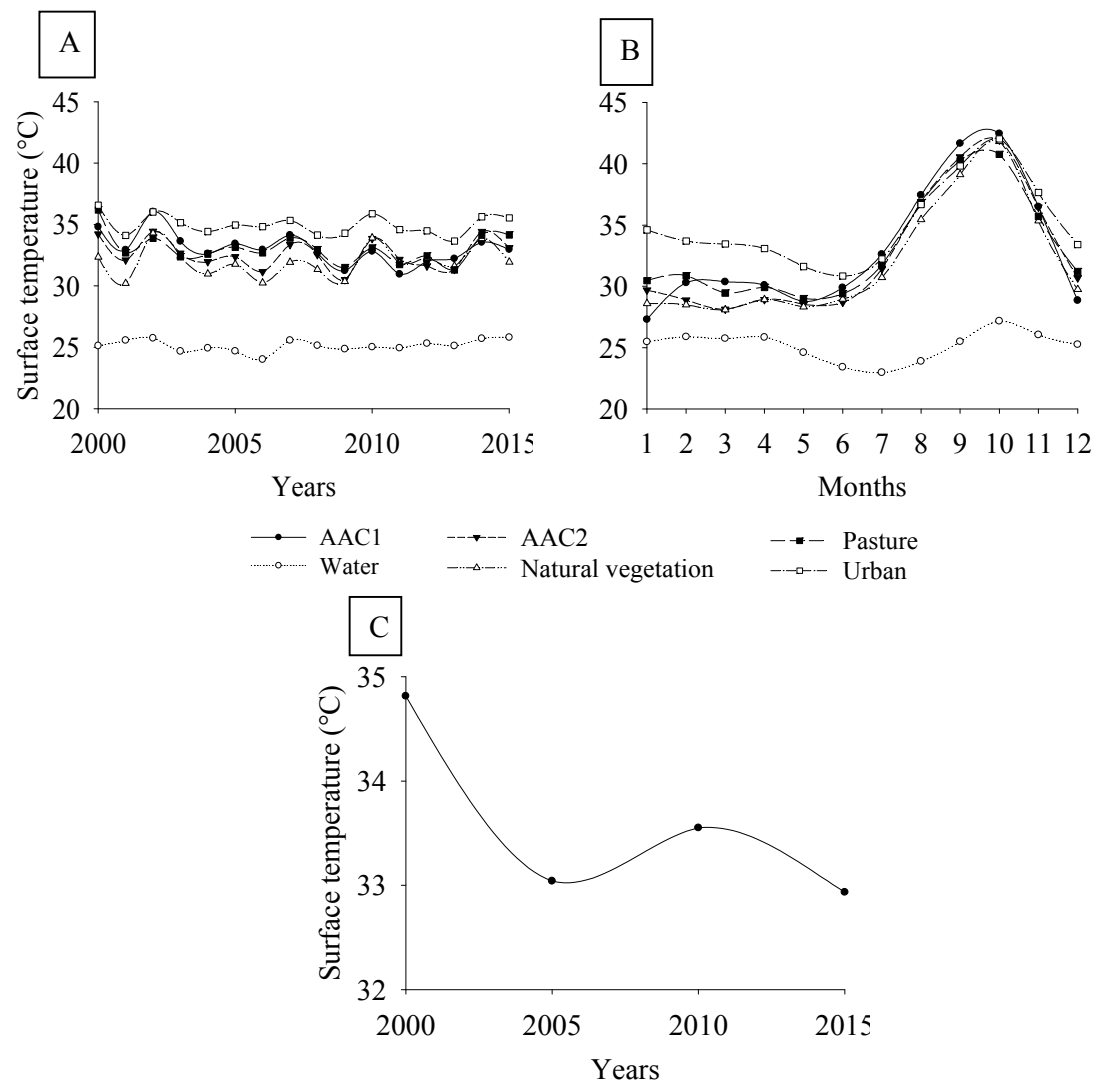

Figure 4. Annual average (A) and monthly average (B) of the surface temperature of the period from 2000 to 2015 for different land uses in the county of Santa Helena de Goias; and surface temperature (C) of the territory of Santa Helena de Goias calculated by the weighted average of all land uses

The lowest averages of ST for the study period were recorded in the areas occupied by water, followed by natural vegetation. The areas occupied by water had lower average surface temperatures because most of the available energy was used for the evaporation process, while the areas occupied by natural vegetation used a large part of the incident energy for the evapotranspiration process, resulting in the cooling of the (Biudes et al., 2015). Between the period 2000 to 2015 (Figure 4A), both had an average ST of $25^{\circ} \mathrm{C}$ and $28{ }^{\circ} \mathrm{C}$, respectively. The use of the soil with the highest ST was the urban area $\left(35^{\circ} \mathrm{C}\right)$, followed by the areas occupied by pasture, $\mathrm{AAC} 2$ and $\mathrm{AAC} 1\left(33^{\circ} \mathrm{C}\right)$. The high values of surface temperature in the urban area are associated with the material of the roofing types, such as concrete, tiles, buildings, and have a high thermal storage capacity. This thermal energy is used only for heating, resulting in increased surface temperature (Pavão et al., 2015).

The areas occupied by natural vegetation in the year of 2006, the average ST was $27{ }^{\circ} \mathrm{C}$, observing that in the year 2007 the average increased to $30{ }^{\circ} \mathrm{C}$, with an increase in ST of this soil use of $3{ }^{\circ} \mathrm{C}$. This increase in ST occurred due to the reduction in precipitation volume in the year 2007 (Figure 5A).

In 2002, it was the year in which it presented higher ST for AAC1, pasture, AAC2 and urban, due to the low volume of precipitation (Figure 5A), reducing EVI2 (Figure 3A) and ETR (Figure 6A). The mean annual ST of the AAC1, pasture and AAC2, had similar behavior for the period from 2000 to 2015, when in the dry period the temperature increases and in the rainy season there is a reduction in the surface temperature (Figure 4B).

While the land uses occupied by AAC1, AAC2, pasture and urban area reach in the month of October ST around $42{ }^{\circ} \mathrm{C}$, the area occupied by natural vegetation reaches its maximum surface temperature peak of $33{ }^{\circ} \mathrm{C}$, positively impacting relation to other land uses (Figure 4B). Mashiki and Campos (2013) cite that soil occupation by natural vegetation presents lower ST, since evaporation converts solar energy into evaporated 
water instead of heat. At ST, values inversely proportional to ETR and EVI2 values were presented. With the change of land use and occupation of natural vegetation for pasture, $\mathrm{AAC} 1$ and $\mathrm{AAC} 2$, there will be an increase in ST (Figure 4A). Lopes et al. (2010), when evaluating the surface temperature in the quantification of the changes of the soil use in the Brígida River Basin, also concluded that the land uses with lower surface temperature increase were constituted by natural vegetation.

By calculating the weighted average, there was a decrease in ST from the county from 2000 to 2015 of almost $2{ }^{\circ} \mathrm{C}$ (Figure 4C), due to the reduction of AAC1 and increase of AAC2 of $97 \%$ that certainly occupied the areas that were previously degraded pasture (Figure 2). Data obtained in this study are in agreement with those obtained by Loarie et al. (2011), where they mention that the increase of the areas occupied by sugarcane has an important benefit, since the conversion of AAC1 and pasture in AAC2 (sugar cane) leads to a substantial local cooler, sugarcane does not replace the benefits of natural vegetation. Since planning is carried out with adequate tools and techniques, the planned expansion of sugarcane can freeze the cerrado directly and indirectly (Loarie, et al., 2011).

\subsection{Precipitation}

Figures 5A and 5B present the annual and monthly precipitation graphs between 2000 and 2015 .
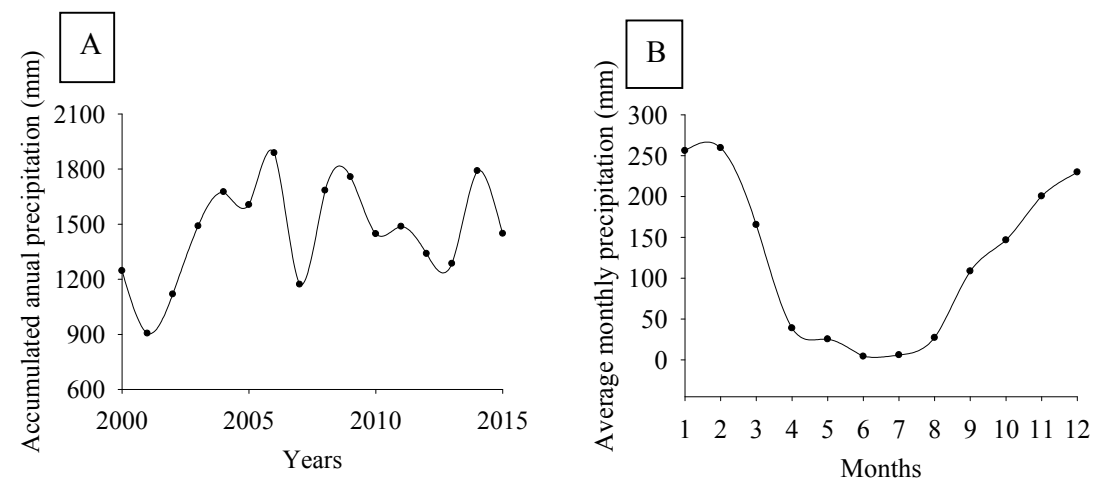

Figure 5. Annual cumulative (A) and monthly average (B) precipitation of the territory of Santa Helena de Goias from the period 2000 to 2015

It can be observed that the distribution of precipitation has great variability during the years studied, with an increase in precipitation volume from 2000 to 2006 and a sharp fall in 2007 (Figure 5A). From the year 2007, it was verified that the precipitation behavior showed high variability. The highest precipitation occurred from September to March (Figure 5B). Nobre (2001) describes that the reduction in global rainfall volume is due to the sun of the decrease due to global climatic changes and to the change in the soil use of areas occupied by natural vegetation to agricultural areas, pasture and sugarcane. Changes in the spatial distribution of precipitation can directly interfere with the response of the vegetation cover, and consequently, the components of the hydrological cycle (Cunha et al., 2012).

The estimation of precipitation through data from the historical series recorded by the remote sensors is of great importance for the elaboration of agricultural zoning and planning for the planting and harvesting of agricultural crops grown in the region.

\subsection{Real Evapotranspiration (ETR)}

Figures $6 \mathrm{~A}$ and $6 \mathrm{~B}$ shows the actual evapotranspiration graphs for the annual and monthly mean, between 2000 and 2013 and Figure 3C shows the total evapotranspiration volume of the county between 2000 and 2013. 


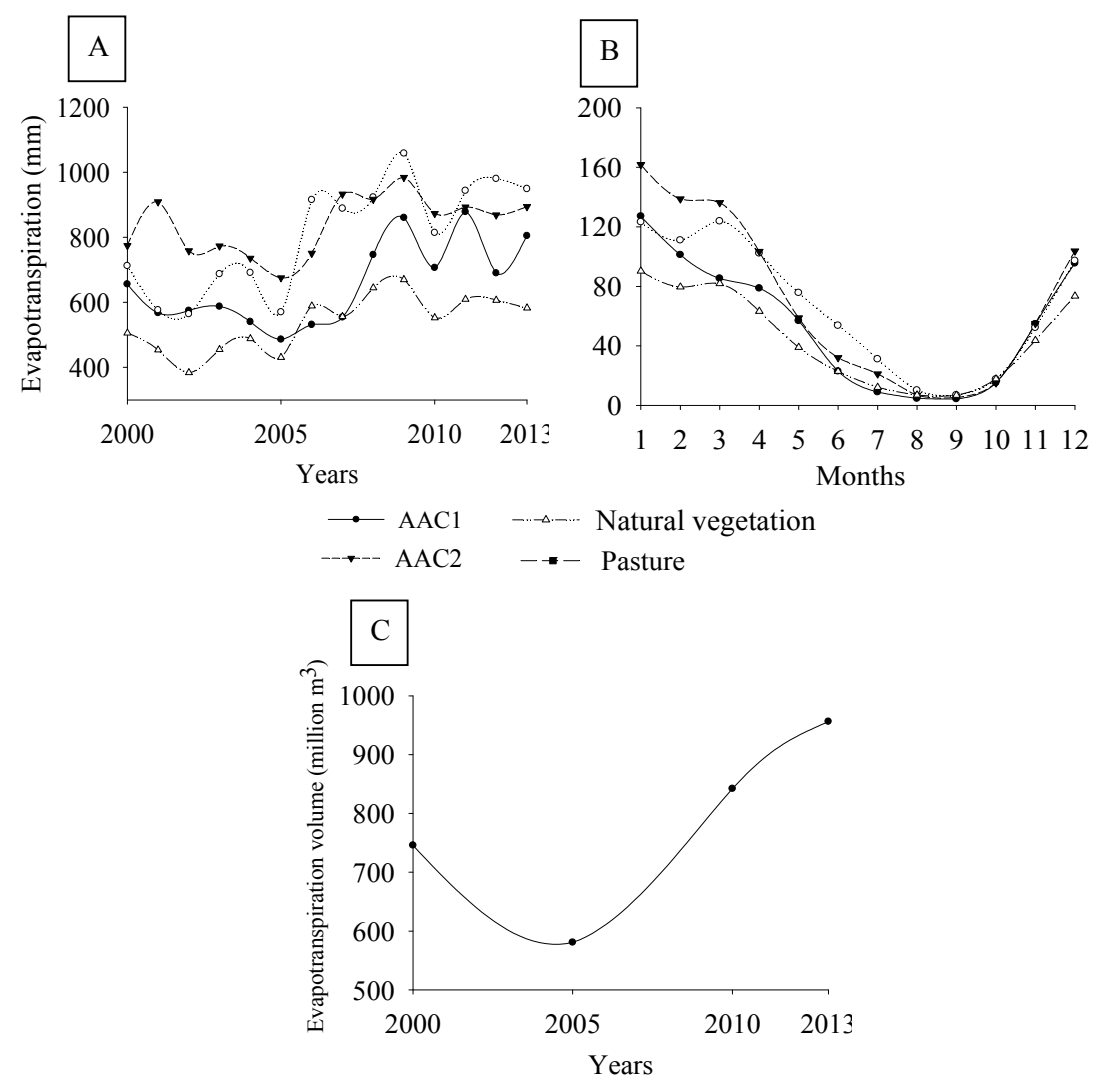

Figure 6. Annual average (A) and monthly average (B) of cumulative evapotranspiration from 2000 to 2013 for different land uses in the county of Santa Helena de Goias; and total volume of evapotranspiration (C) in the territory of Santa Helena de Goias

It was observed that in the period from 2006 to 2013, there was an inversion with the increase of ETR in the areas occupied by natural vegetation from $768 \mathrm{~mm}$ to $888 \mathrm{~mm}$, and AAC2 increased from $636 \mathrm{~mm}$ to $936 \mathrm{~mm}$ (Figure 6A). This increase in sugarcane ETR since 2005 was due to its expansion in the country, adopting cultivars over time that best suits the climatic conditions of the region with a greater absorption of light and loss of water.

In general, areas occupied by natural vegetation had a higher ETR rate, followed by areas of sugarcane, agricultural and pasture, proving that the change in the use and occupation of the natural vegetation soil by any of the uses will cause change in the hydrological cycle. According to Bacellar (2005), the areas occupied by natural vegetation are seen as efficient to stabilize and maintain the water balance. The intensity of the evapotranspiration is a function of the depth of the root system of the plant, because the larger the root system the greater the soil volume explored by the roots, aiming at meeting the water demand of the atmosphere, height and roughness of the plant, since higher and more rugged plants interact more efficiently with the moving atmosphere, extracting more energy from the air, and finally contributing to the increase of evapotranspiration (Pereira et al., 2002).

ETR was high for all soil uses in January due to rainy season (Figure 6B). There was a decrease in evapotranspiration for all land uses from the month of February. The areas occupied by sugarcane presented a higher rate of ETR than the natural, agricultural, pasture, urban and water areas during the months of May to September, due to the fact that during these months sugarcane requires more solar radiation, absorbs more carbon dioxide, and thus the stomata will become open by losing water to the atmosphere (Carmo et al., 2017).

Among the uses of sugarcane, agricultural, natural vegetation and pasture, the use that presented a lower ETR rate was pasture. These results were also found by Feitosa et al. (2009), where the natural areas presented the highest values of ETR and pasture the lowest values. Loarie et al. (2011), cite that the change of pasture soil use for sugarcane favors the increase of ETR. 
It was verified that the volume of ETR for the entire territory of Santa Helena de Goiás in the year of 2000 was 765 million $\mathrm{m}^{3}$ (Figure 6C). From 2000 to 2005, there was a decrease in the volume of ETR of $22 \%$, corresponding to 164.82 million $\mathrm{m}^{3}$ that did not return to the atmosphere, with a change in the hydrological cycle and causing a negative impact on the microclimate not only of the region of study, but also in others. It is verified that this reduction in evapotranspiration volume according to the classification of the land use and the area quantitative (Figure 2) that there was also a reduction of areas occupied by natural vegetation, being that the natural vegetation is responsible for much of the volume of evapotranspiration according to Figure 6A. There was an increase in the volume of evapotranspiration from 2005 due to the expansion of areas occupied by sugarcane (Figure 2). From 2005 to 2010 there was a 44\% increase and from 2010 to 2013, an increase of 13\%, impacting positively.

\section{Conclusions}

The use of the data estimated by satellites found the objective proposed in this work. The change in land use from natural vegetation to agricultural area, sugarcane, urban and pasture, raises the surface temperature, and reduces the annual average vegetation index. Areas occupied by sugarcane have annual mean similar to natural areas for evapotranspiration. The lowest vegetation indexes for all soil uses were recorded from June to October. For the period 2000 to 2015 , the average vegetation index of the county increased. The evapotranspiration volume of the county increased by $28 \%$ from 2000 to 2013 . The surface temperature presented values inversely proportional to the values of evapotranspiration and vegetation index, proving that the urban area presents the highest surface temperature values. The average surface temperature of the county showed a reduction in the period from 2000 to 2015.

\section{References}

Almazroui, M. (2011). Calibration of TRMM rainfall climatology over Saudi Arabia during 1998-2009. Atmospheric Research, 99(4), 400-414. https://doi.org//10.1016/j.atmosres.2010.11.006

Alvares, C. A., Stape, J. L., Sentelhas, P. C., Gonçalves, J. L. de M., \& Sparovek, G. (2014). Koppen's climate classification map for Brazil. Meteorologische Zeitschrif, 22(6), 711-728. https://doi.org/10.1127/09412948/2013/0507

Alves, K. S. da S., Alves, A. V. P., Souza, N. S. E., Sanches, L., Gaio, D. C., Souza, G. S., \& De Musis, C. R. (2017). Análise estatística entre dados de precipitação estimada via satélite TRMM e dados observados de superfície em Praia-Cabo Verde. Revista Brasileira de Climatologia, 21(13) 417-429. https://doi.org/ 10.5380/abclima.v21i0.45865

Andrade, R. G., Bolfe, E. L., Victoria, D. de C., \& Nogueira, S. F. (2017). Avaliação das condições de pastagens no Cerrado Brasileiro por meio de geotecnologias. Revista Brasileira de Agropecuária Sustentável, 7(1), 34-41. https://doi.org/10.21206/rbas.v7i1.376

Bacellar, L. de A. P. (2005). O papel das florestas no regime hidrológico de bacias hidrográficas. Retrived November 1, 2016, from http//:www.degeo.ufop.br/geobr

Bezerra, J. M., Moura, G. B. De, Silva, B. B. Da, Lopes, P. M. O., \& Silva, E. F. de F. e. (2014). Parâmetros biofísicos obtidos por sensoriamento remoto em região semiárida do estado do Rio Grande do Norte, Brasil. Revista Brasileira de Engenharia Agrícola e Ambiental, 18(1), 73-84. https://doi.org/10.1590/S1415-4366 2014000100010

Biudes, M. S., Voulitis, G. L., Machado, N. G., De Arruda, P. H. Z., Neves, G. A. R., Lobo, F. A., ... Nogueira, J. S. (2015). Patterns of energy exchange for tropical ecosystems across a climate gradiente in Mato Grosso, Brazil. Agricultural and Forest Meteorology, 202, 112-124. https://doi.org/10.1016/ j.agrformet.2014.12.008

Caldas, L. S., Machado, L. L., Caldas, S. C., Campos, M. L., Caldas, J. Á., Pharis, R. P., \& Pereira Neto, A. B. (2009). Growth active gibberellins over come the very slow shoot growth of Hancorni aspeciosa, an important fruit tree from the Brazilian "Cerrado". Trees, 23, 1229-1235. https://doi.org/10.1007/ s00468-009-0361-9

Carmo, J. F. A. do, Moura, M. S. B. de, Silva, T. G. F. da, Souza, L. S. B. de, \& Leitao, M. V. B. R. (2017). Balanço de radiação da cana-de-açúcar irrigada por gotejamento subsuperficial no submédio do Vale São Francisco. Revista da Sociedade Brasileira de Agrometeorologia, 25(1), 91-100.

Cuba, N., Rogan, J., Lawrence, D., \& Williams, C. (2018). Cross-Scale Correlation between in situ Measurements of Canopy Gap Fraction and Landsat-Derived Vegetation Indices with Implications for 
Monitoring the Seasonal Phenology in Tropical Forests Using MODIS Data. Remote Sensing, 10(7), 1-21. https://doi.org/10.3390/rs10070979

Cunha, J. E. de B. L., Rufino, I. A. A., Silva, B. B. da, \& Chaves, I. de B. (2012). Dinâmica da cobertura vegetal para a Bacia de São João do Rio do Peixe, PB, utilizando-se sensoriamento remoto. Revista Brasileira de Engenharia Agrícola e Ambiental, 16(5), 539-548. https://doi.org/10.1590/S1415-43662012000500010

Feitosa, D. G., Hernandez, F. B., Franco, R. A. M., \& Teixeira, A. H. C. (2009). Evapotranspiração real para diferentes culturas vegetais no noroeste paulista em período seco. Retrived November 7, 2016, from http://www.agr.feis.unesp.br/pdf/Conird_2012/FEITOSA.pdf

Feitosa, S. M. R., Gomes, J. M. A., Moita Neto, J. M., \& Andrade, C. S. P de. (2011). Consequências da urbanização na vegetação e na temperatura da superfície de Teresina-PI. Revista da Sociedade Brasileira de Arborização Urbana, 6(2), 58-75.

Ferreira, M. E., Miziara, F., Ferreira Júnior, L. G., Ribeiro, F. L., \& Ferreira, N. C. (2009). Ativos ambientais do bioma Cerrado: Uma análise da cobertura vegetal nativa e sua relação com o preço da terra no Estado de Goiás. Revista Brasileira de Cartografia, 61(1), 37-50.

Franco, I. O. (2014). Expansão da cana-de-açúcar na microrregião sudoeste de Goiás: Análise espacial das mudanças do uso e cobertura do solo nos anos de 2001, 2006 e 2011. Boletim Goiano de Geografia, 34(3), 481-499. https://doi.org/10.5216/bgg.v34i3.33860

Gallo, K., \& Xian, G. (2014). Application of Spatially Gridded Temperature and Land Cover Data Sets for Urban Heat Island Analysis. Urban Climate, 8(3), 1-10. https://doi.org/10.1016/j.uclim.2014.04.005

Gomes, H. F. (2009). Balanços de radiação e energia em áreas de cultivo de cana-de-açúcar e cerrado no estado de São Paulo mediante imagens orbitais (Doctoral thesis, Universidade Federal de Campina Grande).

Gomes, L. F., Giongo, P. R., Soares, J. A. B., Oliveira, E. G., \& Luna, D. A. L. (2016). Geotecnologias na análise do uso do solo no município de Santa Helena de Goiás/GO (1995/2015). Desenvolvimento socioeconômico e sustentabilidade do cerrado brasileiro na transposição do século XX para o XXI (1st ed.). Jundiaí: editora Paco.

IBGE (Instituto Brasileiro de Geografia e Estatística). (2016). Retrived July 26, 2016, from http://cidades.ibge. gov.br/xtras/perfil.php?codmun=521930

INPE (Instituto Nacional de Pesquisas Espaciais). (2016). Divisão de Geração de Imagens. Retrived May 1, 2016, from http://www.inpe.br/acessoainformacao/dgi_ativ_sem1_2013

Jensen, J. R. (2009). Sensoriamento remoto do ambiente: Uma perspectiva em recursos terrestres (2nd ed.). São José dos Campos: Parêntese.

LAPIG (Laboratório de Processamento de Imagens e Geoprocessamento). (2016). Retrived May 1, 2016, from http://www.lapig.iesa.ufg.br/lapig

Leite A. P., Santos, G. R., \& Santos, J. E. O. (2017). Análise dos índices de vegetação NDVI e SAVI na estação experimental de Itatinga utilizando imagens LANDSAT 8. Revista Brasileira de Energias Renováveis, 6(4), 606-623. https://doi.org/10.5380/rber.v6i4.45830

Loarie, S. R., Lobell, D. B., Asner, G. P., Mu, Q., \& Field, C. B. (2011). Direct impacts on local climate of sugar-cane expansion in Brazil. Nature Climate Change, 1(2), 105-109. https://doi.org/10.1038/NCLIM ATE1067

Lopes, H. L., Candeias, A. L. B., Accioly, L. J. O., Sobral, M. do C. M., \& Pacheco A. P. (2010). Parâmetros biofísicos na detecção de mudanças na cobertura e uso do solo em bacias hidrográficas. Revista Brasileira de Engenharia Agrícola e Ambiental, 14(11), 1210-1219. https://doi.org/10.1590/S1415-43662010001 100011

Mashiki, M. Y., \& Campos, S. (2013). Influência do uso e ocupação do solo na temperatura aparente da superfície no município de Botucatu/SP. Energia na Agrícultura, 28(3), 143-149. https://doi.org/10.17224/ EnergAgric.2013v28n3p143-149

Monteith, J. L. (1965). Evaporation and environment. The state and movement of water in living organism (pp. 205-234). Symposia of the Society for Experimental Biology. 
Myers, N., Mittermier, R. A., Mittermeier, C. G., Fonseca, G. A. B., \& Kent, J. (2000). Biodiversity hotspots for conservation priorities. Nature, 403, 853-858. https://doi.org/10.1038 / 35002501

Negrón-Juarez, R. I. (2004). Variabilidade Climática Regional e Controle da Vegetação no Sudeste: Um estudo de Observações sobre cerrado e Cana-de-açúcar e Modelagem Numérica da Atmosfera (Doctoral thesis, Instituto de Astronomia e Geofísica da Universidade de São Paulo).

Nobre, C. A. (2011). Mudanças climáticas globais: possíveis impactos nos ecossistemas do país. Parcerias Estratégicas, 6(12), 239-258.

Oliveira, L. M. M., Montenegro, S. M. G. L., Antonino A. C. D., Silva, B. B., Machado, C. C. C., \& Galvíncio, J. D. (2012). Análise quantitativa de parâmetros biofísicos de bacia hidrográfica obtidos por sensoriamento remoto. Pesquisa Agropecuária Brasileira, 47(9), 1209-1217. https://doi.org/10.1590/S0100-204X201200 0900005

Paranhos Filho, A. C., Moreira, E. S., Oliveira, A. K. M. de, Pagotto, T. C. S., \& Mioto, C. L. (2014). Análise da variação da coberturas do solo no Pantanal de 2003 a 2010 através de sensoriamento remoto. Engenharia Sanitária e Ambiental, 19, 69-76. https://doi.org/10.1590/S1413-41522014019010000305

Pavão, V. M., Querino, C. A. S., Beneditti, C. A., Pavão, L. L., Querino, J. K. A. da S., Machado, N. G., \& Biudes, M. S. (2015). Temperatura e albedo da superficie por imagens TM LANDSAT 5 em diferentes usos do solo no Sudoeste da Amazônia Brasileira (Nota de pesquisa). Revista Brasileira de Climatologia, 16(11), 169-183. https://doi.org/10.5380/abclima.v16i0.40128

Pereira, A. R., Angelocci, L. R., \& Sentelhas, P. C. (2002). Agrometeorologia: Fundamentos e aplicações práticas. Guaíba: Livraria e Editora Agropecuária.

Risso, J., Rizzi, R., Rudorff, B. F. T., Adami, M., Shimabukuro, Y. E., Formaggio, A. R., \& Epiphanio, R. D. V. (2012). Índices de vegetação Modis aplicados na discriminação de áreas de soja. Pesquisa Agropecuária Brasileira, 47(9), 1317-1326. https://doi.org/10.1590/S0100-204X2012000900017

Rodrigues, J. O., Andrade, E. M. de, Teixeira, A. dos S., \& Silva, B. B. (2009). Sazonalidade de variáveis biofísicas em regiões semiáridas pelo emprego do sensoriamento remoto. Revista Engenharia Agrícola, 29(3), 452-465. https://doi.org/10.1590/S0100-69162009000300012

Santos, J. S. dos, \& Siqueira, R. (2010). Identificação da dinâmica do uso e cobertura da terra: Expansão da cana-de-açúcar. Retrived November 7, 2016, from http://ess.inpe.br/courses/lib/exe/fetch.php?media=wiki: user:trabalho_final_juliana_padroes.pdf

Shi, Y., \& Song, L. (2015). Spatial Downscaling of Monthly TRMM Precipitation Based on EVI and Other Geospatial Variables Over the Tibetan Plateau From 2001 to 2012. Mountain Research and Development, 35(2), 180-194. https://doi.org/10.1659/MRD-JOURNAL-D-14-00119.1

SIEG (Sistema Estadual de Geoinformações). (2016). Download de arquivos SIG. Retrived May 5, 2016, from http://www.sieg.go.gov.br

Souza, J. F. de, Silva, R. M., \& Silva, A. M. (2016). Influência do uso e ocupação do solo na temperatura da superfície: O estudo de caso de João Pessoa-PB. Ambiente Construído, 16(1), 21-37. https://doi.org/ $10.1590 / \mathrm{s} 1678-86212016000100058$.

Tangdamrongsub, N., Ditmar, P. G., Steele-Dunne, S. C., Gunter, B. C., \& Sutanudjaja. (2016). Assessing total water storage and identifying flood events over Tonlé Sap basin in Cambodia using GRACE and MODIS satellite observations combined with hydrological models. Remote Sensing of Environment, 181, 162-173. https://doi.org/10.1016/j.rse.2016.03.030

USGS (United States Geological Survey). (2016). Retrived May 1, 2016, from http://www.usgs.gov/pubprod

\section{Copyrights}

Copyright for this article is retained by the author(s), with first publication rights granted to the journal.

This is an open-access article distributed under the terms and conditions of the Creative Commons Attribution license (http://creativecommons.org/licenses/by/4.0/). 